Wilfrid Laurier University

Scholars Commons @ Laurier

4-1-2011

\title{
Shaking Up Christianity: The Indian Shaker Church in the Canada- U.S. Pacific Northwest
}

Susan Neylan

Wilfrid Laurier University, sneylan@wlu.ca

Follow this and additional works at: https://scholars.wlu.ca/hist_faculty

\section{Recommended Citation}

Neylan, Susan, "Shaking Up Christianity: The Indian Shaker Church in the Canada-U.S. Pacific Northwest" (2011). History Faculty Publications. 16.

https://scholars.wlu.ca/hist_faculty/16

This Article is brought to you for free and open access by the History at Scholars Commons @ Laurier. It has been accepted for inclusion in History Faculty Publications by an authorized administrator of Scholars Commons @ Laurier. For more information, please contact scholarscommons@wlu.ca. 


\title{
Shaking Up Christianity: The Indian Shaker Church in the Canada-U.S. Pacific Northwest*
}

\author{
Susan Neylan / Wilfrid Laurier University
}

The National Film Board of Canada documentary film O'Siem opens with a contemporary Native American man, Gene Harry, singing and passing his hands over the body of a badly injured man lying unconscious in a hospital bed. ${ }^{1}$ Harry is an Indian Shaker Church minister and, as he describes his approach to healing this man, the juxtaposition between native and Christian spirit ways is apparent:

The first time I got a call from Will's brother Joe, he said that he had a few hours to be with us. When I entered the door and saw the condition of Will, burnt up in a fire, bandaged from his knees to his head, I was shaking inside. I really humbled myself and I asked the Lord to take care of him, wherever, wherever he is. He wasn't, ah, ready to go traveling yet to the other side. And on his prayer he honored me on his wings to travel to different areas and different places where he practiced the healing, not for himself, but for his family. Then when I got to ride on his back, to this day I don't know what he was, a hawk or an eagle. And that's his . . . his power that he has to travel

\footnotetext{
* I am a historian of the indigenous Christian identity in British Columbia and was drawn to the history of the Indian Shaker Church while a Canada-U.S. Fulbright Scholar at the University of Washington, Seattle, in 2006. I gratefully acknowledge the support received from the Fulbright Program and the Foundation for Educational Exchange between Canada and the United States of America. I am aware that the Shaker Church is a living, contemporary institution, and by imposing Western, secular, academic historical analysis, I intend no disrespect. This article constitutes a first foray into a field that I hope to study further and in more collaborative ways with local indigenous communities, particularly on the Canadian side of the border.

${ }^{1}$ A brief note on terminology: "Aboriginal," "Native," and "First Nations" are used in Canada to refer to persons of indigenous descent, while "American Indian" and "Native American" are more commonplace in the United States; I have tended toward using the latter set given the readership of this journal. All are employed in some degree by the Coast Salish and Puget Salish communities on whom this article focuses, although local community and tribal selfdesignations (e.g., Stó:lōor or Snoqualmie) are also employed.
}

(C) 2011 by The University of Chicago. All rights reserved.

$0022-4189 / 2011 / 9102-0003 \$ 10.00$ 
different places. And so we started to move, and my hair started to fly as we traveled and I was still in prayer. I stopped for a moment and opened my eyes and looked around to see where we were, and we were still in the hospital. And, ah, prayer honored me to ride with him to show him where all his gathering of his strength was, where he was resting, where he gathered the red dirt, the streams and the mountains, and the flatlands where he made his medicines strong. ${ }^{2}$

Encounters between indigenous peoples and Christianity rarely have been singular confrontations among spiritual and cultural worlds characterized by unintelligibility, misunderstanding, and opposition, even when speaking of the earliest of interactions. Rather, religious expressions have mutually informed one another. In the late nineteenth and early twentieth centuries the British Columbia-Washington border region was a permeable zone of spiritual exchange among Native American peoples-a religious borderlands where both old beliefs (including Northwest coast ceremonialism, prophet movements, and shamanic practices) and new ones (Christianity and its denominational variations) were disseminated in the multiethnic, cross-cultural environment. The region spawned a number of distinctive cross-border religious movements that blended Native American traditions with Christian ideas, ranging from Christian revivals and camp meetings to the emergence of several visionaries and prophets who incorporated Christianity into ceremonial practices. ${ }^{3}$ These phenomena raise questions about shifting or multiple identities within religious culture. One of the most fascinating is the Indian Shaker Church. In the early 1880s a Coast Salish man from the Squaxin nation in southern Puget Sound received a message from the Christian heaven that became the foundation of a new church. ${ }^{4}$ Departing from mission forms of Christianity in fundamental

${ }^{2}$ Gillian Darling, director, and George Johnston, producer, O'Siem (Tamarin Productions and National Film Board of Canada, 1996).

${ }^{3}$ The classic work on this topic is Leslie Spier, The Prophet Dance of the Northwest and Its Derivatives: The Source of the Ghost Dance (Menasha, WI: Banta, 1935).

${ }^{4}$ Contrary to what the name might suggest, this church has no connection to the other Shakers of the eastern United States-the United Society of Believers, founded in early eighteenth-century England and brought to America (especially New York state) in the 1770s under the leadership of Ann Lee. Known also as the "Shaking Quakers" (they were originally a splinter group from the Quakers, who often shook and had visions while under the influence of the Holy Spirit), they believed in the imminent second coming of a dual-gendered God (making the role of women in the sect important) and dedicated themselves to simple lives, communal living, and celibacy. Historians Robert H. Ruby and John A. Brown offer one explanation of the term: "the phonetic English equivalent of the Puget Sound Salish word for 'shaking' evolved as Chaddon. Another English name for shaking is Tschaddam, a term said to have been given in jest to Slocum's followers by other Indians. The name 'Slocum tum-tum' from the Chinook Jargon for 'heart' was applied to Slocum's followers because it sounded somewhat like Tschaddam"; John Slocum and the Indian Shaker Church (Norman: University of Oklahoma Press, 1996), 41. 


\section{The Journal of Religion}

ways, not the least of which were its indigenous origins and the subsequent insistence of the Indianness of the church, Shakerism was not simply old Indian ways with a Christian veneer. Since the church's inception through to the present day, scholars have grappled with interpretative frameworks-from revitalization movement to cultural continuity-in their descriptions and analyses of this Native American Christian institution. ${ }^{5}$

This essay offers an introductory overview of Indian Shakerism and its historiography. It proceeds from the idea that Shakerism can be read as a countercolonial performance-that is to say, one that appropriates Christianity and reinscribes Native American cultural traditions within, yet also against, a colonial world. ${ }^{6}$ By utilizing performance as the conceptual lens through which the Indian Shaker Church can be assessed in the archival, oral, and scholarly records, Shakerism can be appreciated as a vehicle for self-representation and the expression of both a native and a Christian identification. ${ }^{7}$ As historian James Treat puts it, "the terms 'native' and 'Christian' categorize humanity in ways that are both ambiguous and contested," even more so when combined into the single moniker of "Native Christian." ${ }^{\circ}$ To what degree can Indian Shakerism be read as a comparative dialogue within Native American com-

\footnotetext{
${ }^{5}$ The best discussion of the historiography of the Shaker Church remains Pamela T. Amoss, "The Indian Shaker Church," in The Handbook of the North American Indian, vol. 7, The Northwest Coast, ed. Wayne Suttles (Washington, DC: Smithsonian Institution, 1990), 633-39. This was prior to former church bishop Harris Teo's donation of the Indian Shaker Church of Washington records to the Washington State Historical Society that subsequent scholarship has been able to draw upon.

${ }^{6}$ The term "postcolonialism" is often used by scholars with only a vague sense of its meaning, ranging from anything related to former colonial societies and their voices (e.g., decolonized indigenous peoples and/or Third World writers) to critical reassessments of colonialism/ neocolonialism from decolonized and still colonized perspectives. For a good discussion of current postcolonialisms and the fluid definitions developed in various fields and subdisciplines, see Gaurav Desai and Supriya Nair, eds., Postcolonialisms: An Anthology of Cultural Theory and Criticism (New Brunswick, NJ: Rutgers University Press, 2005). However, as the period and region that spawned the Indian Shaker Church was straightforwardly "colonial," I have adopted the term "countercolonial," after the concept of alternative or counterhegemony whereby power structures are inverted, ignored, or subverted in order to empower the disempowered-in this context, the colonized. It is more complex than simply reacting to or resisting colonialism, as it entails cultural change, the adoption as well as rejection of colonial forms, and harmonizing with colonial powers (i.e., not always in friction with them). This includes appropriation of the hitherto "colonial" Christian religion and the indigenizing of it.

${ }^{7}$ Shakers themselves would likely deny that what they believe and practice was any part of conscious resistance or engagement with colonialism. Rather, I speculate, they might view it as an identity/mode of identification, and not a performance at all. For a discussion of the utility of "identification" rather than "identity" as an analytical framework, see Rogers Brubaker and Frederick Cooper, "Beyond 'Identity," Theory and Society 29 (2000): 14-17.

${ }^{8}$ James Treat, Native and Christian: Indigenous Voices on Religious Identity in the United States and Canada (New York: Routledge, 1996), 2.
} 
munities about the place of Christianity in native religious cultures and the place of native beliefs and practices within Christian contexts? This essay begins with a brief description of spirituality within the Coast Salish/Puget Salish world, with an emphasis on how spiritual power was historically acquired and how relationships with otherworldly and nonhuman beings were established through performance and ceremony. Next, it examines the historical encounter with Christianity by Coast Salish peoples, its expression in the form of the Indian Shaker Church, and the reception it received by Indians and non-Indians alike. One of the striking characteristics of Shakerism has been the primacy given to orality and unmediated access to spiritual power. Tensions between experiential/oral and mediated/textual authority within its practices and expressions ultimately led to schisms within the Indian Shaker Church by the mid-twentieth century. Finally, this essay considers the ethnohistoriography of Shakerism. How have different groups-ranging from nineteenth-century missionaries and mid-twentieth-century academics to Indian Shakers themselves-understood this indigenous form of Christianity? The Indian Shaker Church has been analyzed in the scholarly literature in antiquated and oversimplified ways. How might the conceptual framework of performance refocus how we view this religious movement in a way that harkens back to Salish modes of spiritual innovation, as recent trends in historiography seek to emphasize?

Cultural encounters and the "contact zones" they create come in many forms. ${ }^{9}$ Whether highly ritualized or informal interactions, these contacts are above all forms of communication and performance, which, in the words of cultural historian Rhys Isaac, encompass "language, gesture, demeanour, dress, and architecture. Thus society emerges as a series of images that participants have of their own and others' performances." ${ }^{10}$ When the Native American peoples of the Pacific Northwest were introduced to Christianity, it was undeniably a

\footnotetext{
${ }^{9}$ Mary Louis Pratt (Imperial Eyes: Travel Writing and Transculturation [London and New York: Routledge, 1992], 4) coined the phrase "contact zone" to refer to "social spaces where disparate cultures meet, clash, and grapple with each other, often in highly asymmetrical relations of domination and subordination-like colonialism, slavery, or their aftermaths as they are lived out across the globe today." Other scholars have adapted this idea implemented as a literary approach, to describe how native-newcomer contacts historically should be seen as processes, rather than events, that occur across both space and time. See, e.g., John Sutton Lutz, ed. Myth and Memory: Stories of Indigenous-European Contact (Vancouver: University of British Columbia, 2007).

${ }^{10}$ William H. Beezley, Cheryl English Martin, and William E. French, "Introduction: Constructing Consent, Inciting Conflict," in Rituals of Rule, Rituals of Resistance: Public Celebrations and Popular Culture in Mexico, ed. William H. Beezley, Cheryl English Martin, and William E. French (Wilmington, DE: Scholar Resources, 1994), xv; citing Rhys Isaac, The Transformation of Virginia, 1740-1790 (Chapel Hill: University of North Carolina Press, 1982), 323-57.
} 
collision, but it was paradoxically also the continuation of spiritual ideas and powers among native peoples that had long informed cultural exchange throughout the region. Scholars writing about Native American performances in the postcontact context in this region of the world inevitably connect them to cultural representations and, in particular, stress how an "Indian" identity is communicated through culturally mediated performance. ${ }^{11}$

On one level, the term "performance" is a problematic label because it suggests an audience separate or separated from the performers and also hints at artifice, affectation, and explicit intention in the engagement. With a few public exceptions during the early days of the church, Shakerism was a self-contained, even closed performance (although the church itself was not closed). ${ }^{12}$ Moreover, unless we are adopting the nineteenth-century missionary appraisal of this particular religious innovation, we find nothing disingenuous or pretended about Shakers. As historian Paige Raibmon cautions, there is a danger to reading "authentic Indian" performances only as a response to the colonial encounter:

Far from being smothered by a blanket of false consciousness, Aboriginal people twisted and transformed colonial concepts like authenticity in service of their own diverse and (for colonizers) unexpected ends. . . . Aboriginal communities-like many others-crafted tradition and continuity through repeated and contested use. Emblems of cultural difference were broadly shared at the same time as they held varied meanings for different individuals. ${ }^{13}$

The lens of performance allows for a way of seeing more varied and complex characteristics within Native American spiritual cultures and in native Christian identification itself, moving us beyond the simplistic dichotomies of victim/agent or resistor/collaborator. Therefore, when we view performance related to religious contact zones in the Pacific Northwest on a much broader level, it is a form of communication about culture, identity, and spirituality. In a way, this is closer to Coast Salish/Puget Salish concepts of spirit power itself, where it is never passively received or given but instead is activated by ceremony and

\footnotetext{
${ }^{11}$ For a good overview of the fast-evolving historical literature on Native Americans and performance, see Philip Deloria, Indians in Unexpected Places (Lawrence: University Press of Kansas, 2004), and his earlier work Playing Indian (New Haven, CT: Yale University Press, 1998).

${ }^{12}$ As the authors of the most recent monograph on Shakerism (Ruby and Brown, John Slocum, xv) explain: "Despite a long history of opposition from government officials and leaders of different mainstream Christian denominations, the Shakers continue to welcome outsiders and tolerate slippage from within."

${ }^{13}$ Paige Raibmon, Authentic Indians: Episodes of Encounter from the Late-Nineteenth-Century Northwest Coast (Durham, NC: Duke University Press, 2005), 12.
} 
performance. New spiritualities, including Christian ones, were likewise reckoned through performance.

\section{SETTING THE STAGE: THE NATURE OF COASTAL SPIRITS}

The Native American peoples at the center of my study are primarily the Coast Salish, encompassing native peoples living in the Puget Sound ("Salt Water") region of present-day Washington state in the United States and southeastern Vancouver Island and the lower Fraser River watershed region (S'ólh Téméxw) of mainland British Columbia on the Canadian side of the border. ${ }^{14}$ The Puget Salish call themselves $d x^{w}$ lašucid, or the people of the Salt Water, in the Lushootseed (Whulshootseed) language, while the Coast Salish of the Upper Fraser River use the Halq'emélyem (the Upriver [Fraser] dialect of Halkomelem) term Xwélmexw to signify those who speak the same language. Prior to the reservation and reserve systems imposed in the second half of the nineteenth century along with Westernized systems of local governance, there were hundreds of "named groups or 'tribes,' each having one or more winter villages, several summer camps, and resource sites." ${ }^{15} \mathrm{El}-$ ders and anthropologists alike have defined these societies as animated social networks where "ties of marriage, joint feasting and ceremonial activities, and use of common territory linked neighbouring groups." ${ }^{" 16}$

\footnotetext{
${ }^{14}$ Many Coast Salish groups living in the present-day United States use the label "Puget Salish" or Lushootseed ( $d x^{w}$ iəšucid) after the dialects they share in common. Lushootseed (or sometimes spelled Whulshootseed or $(t)$ xwiəšucid) comes from two words, "salt water" and "language," and thus translates roughly as "the People of the Salt Water." Halkomelem-speaking Coast Salish on the Canada side of the border use different self-designations. Halq'eméylem is spoken by Upper Fraser River Coast Salish, Hun'qumyi'num' is the downriver (Fraser) variant, and Hul'q'umín'um' is the Vancouver Island dialect. While the Indian Shaker Church touched all three Halkomelem groups, I have opted to follow Halq'emélyem spellings, although no exclusivity is intended. Xwélmexw is the Halq'emélyem word for human beings who speak the same language, commonly used by those mainland Coast Salish on the Canada side of the border, while S'ólh Téméxw is their label for their homelands. Throughout this essay, when I employ Native American terminology, and if applicable, the Halq'emélyem word is followed by the Lushootseed or $d x^{w}$ lišucid version. Coll-Peter Thrush, "The Lushootseed Peoples of Puget Sound Country," University of Washington Libraries Digital Collections, http://content.lib.washington.edu/aipnw/thrush.html; Zalmai Zahir, "About Lushootseed," http://pugetsalish.com/welcome.aspx; Dawn Bates, Thom Hess, and Vi Hibert, Lushootseed Dictionary (Seattle: University of Washington Press, 1994); Lushootseed words used in this essay follow Bates, Hess, and Hibert; Keith Thor Carlson, ed., A Stó:lo-Coast Salish Historical Atlas (Chilliwack: Stó:lo Heritage Trust; Vancouver: Douglas \& McIntyre; Seattle: University of Washington Press, 2001), 24-29, plate 8 (Halq'emélyem words used in this essay follow Carlson).

${ }^{15}$ Wayne Suttles and Barbara Lane, "Southern Coast Salish," in Suttles, ed., Northwest Coast, 485.

16 "These ties were especially strong within the same waterway or drainage system, but there were no breaks in the social system, which extended throughout the . . . Coast Salish region
} 
Common language, the significance of watersheds, cohesion derived from shared mythic ancestors and ongoing family relations, and shared cosmologies are all cultural expressions of their collective identity. ${ }^{17}$ Social, cultural, and economic ties also linked these peoples to interior Salish groups, and sometimes to non-Salish speakers (such as the Nuuchah-nulth on the west coast of Washington and Vancouver Island).

Religion permeates all aspects of Salish life, and strict distinctions like secular and religious do not really exist as discrete categories. ${ }^{18}$ To understand how Salish peoples engaged Christianity in the form of the Indian Shaker Church as a culturally mediated performance, one has to first appreciate the degree to which ritualized performance has long been a characteristic of Salish relations with spiritual power. Spiritual expressions were often based on the assumption that humans can acquire spiritual power through direct contact with more-than-human or nonhuman beings. This was commonly accomplished through winter or longhouse dancing (smílha and syúwél; píg ${ }^{z w}$ ed) or a vision quest (čálcut

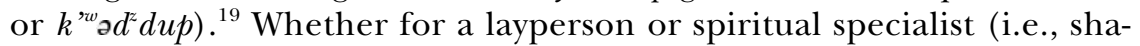
man or Indian doctor, called shxwlá:m and $\left.d x^{w} \sqrt{ } d a ́ ? a b\right)$, contact with nonhuman beings was inherently dangerous and could result in death if one was not properly prepared (e.g., ritual preparations such as fasting and purifying, strict observances of taboos, or mediation by those already empowered). When successful, individuals received a song and dance that was "at the same time visible proof of his [or her] contact and the means to mobilize the power of the vision. The . . . experience is an intensely private affair and no one else has any right to mediate between the seeker and his [or her] vision. The song and dance is part of this public demonstration of the seeker's supernatural power and as such must conform to certain cultural standards," which often included prohibitions against discussing it outside of its performative context or among the uninitiated. ${ }^{20}$ Stó:lō leader and teacher Naxaxalhts'i, also

and beyond" (Suttles and Lane, "Southern Coast Salish," 485). See Carlson, Stó:lo-Coast Salish Historical Atlas, 24-33, plates 8-10.

${ }^{17}$ Carlson, Stó:lō-Coast Salish Historical Atlas, 24-29, plate 8.

${ }^{18}$ June McCormick Collins, Valley of the Spirits: The Upper Skagit Indians of Western Washington (Seattle: University of Washington Press, 1974), 144.

${ }^{19}$ The Halq'emélyem term for gathering for the winter dance is smilha, while the syúwél refers to the winter dancing itself, so called after the power(s) manifested during the ceremony. Similarly, the Lushootseed terms for spirit power, $s \sqrt{ }$ qəšlálitut or $s \sqrt{ }$ yəšw'd, are applied to both the source and manifestation of power (and, hence, applicable to winter dancing), although in some dialects, such as that of the Duwamish, píg $g^{w}$ šd (spirit power ceremony) is used for winter dances. The words for vision quest included here are the Lushootseed terms only.

${ }^{20}$ Pamela Amoss, Coast Salish Spirit Dancing: The Survival of an Ancestral Religion (Seattle: University of Washington Press, 1978), 48. Evangelical Protestantism had a similar experience with meetings full of hymns and the practice of testimonials, whereby the moment and 
known as Albert (Sonny) McHalsie, puts it more directly: "If something special happens to us, we're not allowed to tell it. . . . That's why a lot of our people don't talk about that because we're taught that something special like that is something we need to keep to ourselves. . . If you talk too much about it, it loses its power."

Hence, the spirit world for these peoples was apart from, but similar and connected to, the human world, and it was often performance itself that facilitated the interaction. Indeed, several spiritual forces coexisted with one's corporeal form, and the bonds this created for the collective transcended any individual experience. ${ }^{22}$ Over time, the maintenance of this relationship between worlds became a significant characteristic of the religious life of Xwélmexw and $d x^{w} l$ lašcid. "By preparing for such a contact, undergoing the trial, and reemerging endowed with the fruits of the spirit-encounter, one fulfilled the precepts of religious action. The process completed its cycle with the reintegration at a communal ritual of the person, with his or her new powers, into human society." ${ }^{23}$ While spirit helpers (sxwó:yxwey and syúwél or ó:lkwlh when referring to those manifest in the winter dance ceremony; $k^{w} a x^{w} a d a d$ ) could influence their owners' lives at any time (shamans in particular were gifted at receiving assistance from them whenever needed), they manifested themselves seasonally each winter, when performances, usually referred to as spirit or winter dancing, activated their presence. ${ }^{24}$ Singing, dancing, and special regalia—the gifts from one's spiritual helpers-featured prominently in the winter gatherings that functioned to renew the relationship between humans and nonhumans/more-than-humans. ${ }^{25}$ Along

meaning of one's rebirth in Christ is recounted and retold. Unlike previous traditions of empowering one's vision, this was done publicly (and of course, minus the dancing). While often formulaic, Christian testimony allowed the convert to relive the intensely emotional experience of conversion in a group setting. Usually the disclosure of one's vision impeded the acquisition or retention of the power received. However, sometimes with new religious forms imported from outside local cultural traditions, the normal rules and procedures were inverted. The public disclosure of one's Christian vision, therefore, may not have been at odds with prior practices after all.

${ }^{21}$ Naxaxalhts'i, Albert (Sonny) McHalsie, "We Have to Take Care of Everything That Belongs to Us," in Be of Good Mind: Essays on the Coast Salish, ed. Bruce Granville Miller (Vancouver: University of British Columbia Press, 2007), 124.

${ }^{22}$ Carlson, Stó:lō-Coast Salish Historical Atlas, 28.

${ }^{23}$ Pamela T. Amoss, "Resurrection, Healing, and 'the Shake': The Story of John and Mary Slocum," Journal of the American Academy of Religious Studies, Thematic Studies 48, nos. 3-4 (1982): 99.

${ }^{24}$ Collins, Valley of the Spirits, 145.

${ }^{25}$ Nonnatives in early written records referred to them using the Chinook Jargon tamahnous, but "guardian spirit," "spirit dancing," "big house dancing," syéwen (Haq'emélyem for what is given the guardian spirit, such as the song or dance) or "spirit power," and even "pow-wow" are words used in the contemporary context to describe the winter spirit dancing complex. J. E. Michael Kew, "Central and Southern Coast Salish Ceremonies since 1900," in Suttles, ed. Northwest Coast, 476. An interesting twentieth- and twenty-first-century adaptation has been 
with seasonality, many spirit powers/helpers were linked to specific sites on the land or water. ${ }^{26}$ The place of territoriality within the Indian Shaker church is less clear, although this may be one of the elements influencing regional and localized variations of the church.

One of the important functions of spirit dancing was the ability to heal sickness caused by exposure to spiritual power and/or nonhuman elements. As anthropologist Wayne Suttles explains it, a being that a particular individual had come into contact with in a vision quest ( $c$ 'alcut or $k^{w} ə d^{z} d u p$ ) returned one winter, making that person ill:

A shaman or ritualist recognized the sick person as . . "a new dancer" and helped him [or her] to learn to control his [or her] song and . . . to dance with it in a state of possession. Spirit songs also came unsought to persons suffering from grief. They could also be induced to possess persons by means of ritual abduction and isolation. . . . Each winter, persons with songs acquired in these various ways danced at public gatherings held for the purpose. ${ }^{27}$

In other words, the dancers healed themselves through performative engagement with their spiritual gifts. The importance of spiritual encounters with nonhuman powers, the receipt of gifts, the seasonal ritual affirmation of that connection with those spiritual forces and helpers, and the function of religious practices for healing, were all aspects that later informed the Coast Salish and Puget Salish interpretations of Christianity. They shaped the central tenets of the Indian Shaker Church in particular.

\section{THE PERFORMANCE BEGINS: INDIGENIZING CHRISTIANITY AND THE} INDIAN SHAKER CHURCH

Communicating with spiritual beings and mastering new religious ideas were a key part of the native-newcomer encounter realized in this area of North America in the late eighteenth and especially in the early nineteenth century. The same trade routes that brought Euro-American goods also brought a diversity of religious beliefs and practices to native peoples on the Pacific Coast. Although fur traders were not immediately interested in Christianizing their new trading partners, they exposed them to varied levels of Christian piety and Christian practices, such as

to combine potlatching with spirit dancing, something that Wayne Suttles has written extensively about in, for example, "Spirit Dancing and the Persistence of Native Culture among the Coast Salish," in his Coast Salish Essays (Seattle: University of Washington Press, 1987), 199-230.

${ }^{26}$ Albert (Sonny) McHalsie, "Stl'áleqem Sites: Spiritually Potent Places in S'olh Téméxw," in Carlson, Stó:lo-Coast Salish Historical Atlas, 10-11.

${ }^{27}$ Suttles, "Spirit Dancing," 204. 
Sabbath observance, Christmas celebrations, making the sign of the cross, and singing hymns. Native American curiosity in this new belief system manifested itself in indigenous prophet (syú:we) movements with Christian characteristics and the general dissemination of Christian symbols, ideas, and practices before any direct involvement of European or American missionaries (which for the Pacific Northwest was not until the 1830s and 1840s). ${ }^{28}$ Native Americans also believe that their own shamans, visionaries, and dreamers accessed Christian power or predicted its arrival long before the coming of missionaries in the first half of the nineteenth century. ${ }^{29}$ Consequently, when many Indians in the region first heard Christian teachings, it was not necessarily always from nonnatives. The belief in and insistence on indigenous origins for certain forms of Christianity can be one measure and central characteristic of a Northwest Coast Indian "performance" within the native-Christian encounter.

At the same time, one cannot portray what occurred in these "missionlands," after widespread activity by Protestants and Roman Catholics had gained momentum by the middle of the nineteenth century, merely as a benign process in which Native Americans always had a role to play in interpreting the new religion. The process of missionization was most definitely an arm of the colonialism; native peoples suffered direct attacks on their cultures, belief systems, and their very lives because of Christian missions. Some of the darkest legacies of colonialism in both Canada and the United States that remain unresolved and unhealed today are historically related to this process-residential schools or Indian boarding schools among them. In 1884, when the Canadian government implemented the potlatch ban through an amendment to the Indian Act, it also extended the ban to many traditional forms of spirituality and the ceremonial contexts through which they were expressed, such as spirit dancing. Many such forms and their practitioners were grouped under the Chinook Jargon catch-all term tamahnous, which carried negative connotations. ${ }^{30}$ Territorial and state prohibitions

\footnotetext{
${ }^{28}$ Spier suggests this in Prophet Dance of the Northwest, 30-31, 64-65. Christian Iroquois (Roman Catholic) are also referred to throughout Suttles, Northwest Coast (see esp. 119, 127, 499).

${ }^{29}$ Carlson, Stó:lo-Coast Salish Historical Atlas, 155-56; and Susan Neylan, "Encountering Spirits: Evangelical and Holiness Revivals in Victoria, B.C., and the 'Colonial Project," Histoire Sociale/Social History 36, no. 71 (May 2003): 175-204.

${ }^{30}$ The Chinook Jargon is a material-based adaptive language, originating among pre-Columbian Native Americans throughout the Pacific slope as a means to communicate in what otherwise was a linguistically diverse environment. After the arrival of Europeans in the Pacific Northwest, Chinook Jargon (also called Wawa) remained for nearly two centuries an important way different populations spoke to each other or even among themselves. It incorporated
} 
against the tamahnous and the patronage of spiritual healers or shamans ("Indian doctoring" in the vernacular) led to the persecution of traditional religious practices with which their spiritual powers were associated. ${ }^{31}$ It was undeniably this inhospitable colonial context that drove Shakers to incorporate their church and to attempt to receive legal protection for their practices under United States law. ${ }^{32}$

The roots of the Indian Shaker Church date back to 1882, when a Squaxin man from southern Puget Sound, John Slocum, died and was resurrected. He claimed to have received a message from the spirit world that became the founding principles of a new church-in return for giving up gambling, tobacco, alcohol, and native medicine (including the patronage of shamans), salvation was promised. Slocum himself had failed to follow these proscriptions and within the year fell mortally ill. His wife, Mary Thompson Slocum, who had followed her husband's vision devoutly, was overcome with tremors while praying. When she shook over his body, she healed him, in an apparent fulfillment of the promise John had first received. Many of the Slocums' followers acquired the ability to heal through "the shake"-hence the church's name-and healing remains one of the organization's highest priorities.

On the advice of a nonnative lawyer (James Wickersham), the Slocums' followers adopted the organizational structure that saw them legally recognized as a church in 1892 and officially incorporated as the Indian Shaker Church of Washington under state law in 1910 (aided again by a nonnative, justice of the peace Milton Giles, who continued to work for the Shakers as an organizer)..$^{33}$ The right to take advantage of guarantees of religious freedom (a category partially extended to Native Americans after 1887 and fully in 1924) was something that

\footnotetext{
Native American words and grammar alongside French and English ones, and in the nineteenth century on both sides of the Canada-U.S. border it could be heard in canneries, hop yards, timber camps, trading posts, and missions. For further information see George Lang, Making Wawa: The Genesis of Chinook Jargon (Vancouver: University of British Columbia Press, 2008); Jim Holton, Chinook Jargon: The Hidden Language of the Pacific Northwest (San Leandro, CA: Wawa Press, 2004).

${ }^{31}$ A ban against "Indian doctoring" was issued by the Superintendent of Indian Affairs of Washington Territory as early as 1871; Erna Gunther, "The Shaker Religion of the Northwest," in Indians of the Urban Northwest, ed. Marian Smith (New York: Columbia University Press, 1949), 41.

${ }^{32}$ Protection was not really afforded Native American religious practices until the American Indian Religious Freedom Act of the 1970s, and even then those freedoms were frequently contested. My thanks go to one of my peer reviewers for this point of clarification.

${ }^{33}$ Wickersham's motivations were not entirely altruistic. As historian George Castile points out, "he was deeply involved in the opening of Indians' land to white developers ("The 'HalfCatholic' Movement: Edwin and Myron Eells and the Rise of the Indian Shaker Church," Pacific Northwest Quarterly 73, no. 4 [October 1982]: 166). See also George P. Castile, "The Indian Connection: Judge James Wickersham and the Indian Shakers," Pacific Northwest Quarterly 81, no. 4 (October 1990): 122-29.
} 
would not have been available had the gift of "the shake" first come to Canadian aboriginal groups (where full citizenship was denied to First Nations in Canada until 1960). ${ }^{34}$ However, by the early twentieth century, Shakerism had spread throughout the region and across the border into Canada (specifically to the Musqueam people on the lower mainland at the mouth of the Fraser River and to the Cowichan and Chemanius First Nations in southeastern Vancouver Island). The Shaker Church enjoyed more legal stability in the United States. By the twentieth century the bulk of the church buildings were either held in deed by the Shakers as a group, allotted to individual Shakers, or assigned to the church, whereas Canadian churches occupied reserve lands only through band council permission. ${ }^{35}$

Scholars examining the Indian Shaker Church's organizational structure and central tenets acknowledge that, while the church is undeniably Christian in principle, it actively combines Native American styles of song, movement, and oral declarations in its expression. ${ }^{36}$ The Shaker Church has elected officials (such as its bishop) and licensed preachers and missionaries, positions to which both women and men can be selected. However, rank does not necessarily determine the roles members

\footnotetext{
${ }^{34}$ After the passage of the Dawes Severalty Act in 1887, more aboriginals came to live on private property. The Dawes Act provided for the allotment of lands in severalty to reservation natives, thereby reducing the size of tribal holdings substantially as pieces of reservations were converted into individually owned plots of lands. The act also placed "Indians" under U.S. law and made them U.S. citizens (although the majority of Native Americans did not receive American citizenship until 1924). This proved to be an important development in indigenous expressions of religion, for it meant that ceremonial facilities or church buildings could be built on private lands, which, at least in principle, remained out of the reach of Indian agents. Furthermore, native peoples had, as U.S. citizens, recourse to the full force of American law to protect their religious rights, something that was utilized to their advantage in the case of the Indian Shaker Church. In British territory, the situation developed quite differently. Until the mid-nineteenth century, nonaboriginal numbers remained very small (in fact, when British Columbia joined Canada in 1871, 80 percent of its population was still aboriginal). Aside from a few land cession treaties (known as the Douglas Treaties) on Vancouver Island in the 1850s for lands around Hudson's Bay Company trading posts (accounting for less than 3 percent of the island's land mass), next to no treaties between First Nations and the British for the lower mainland were ever made. Indeed, with recent exceptions, such as Treaty 8 (1899), covering the northeastern corner of the province, and the Nisga'a treaty (the final agreement went into effect in 2000), encompassing the Nass River watershed in northern British Columbia, most aboriginal peoples in British Columbia have never ceded land or rights to resources (even to this day). After 1871, when British Columbia joined the confederation, aboriginal peoples in the province fell under federal jurisdiction. The Canadian Indian Act legally defined "Indian," based on patrilineal descent (and therefore, who was eligible to live on reserves held in trust for the Indians by the crown, or who could receive treaty benefits), and made "Indians" wards of the state-a status that denied them full rights of citizenship including the franchise or ability to preempt land.

${ }^{35}$ Building deeds to Shaker Church lands, 1908-91, Indian Shaker Church of Washington Records, MS 29, box 2, folder 40, Washington State Historical Society Reading Room, Tacoma.

${ }^{36}$ Ruby and Brown, John Slocum, xv.
} 
adopt during their healing work (often referred to as simply "the work")-some services are conducted without a preacher present. Instead the power to heal through shaking resides in individuals; collectively the congregation unites in support, a unity deemed equally necessary to the successful exercise of their divine gifts. ${ }^{37}$ This adaptation to Christian authority harkens back to Native American beliefs in unmediated encounters with the spirit world. Shakers believe in an omnipotent God, his Savior son Jesus Christ, and the Holy Ghost and further believe that the "spirit of God" empowers them to "shake" (without which one could not be a church member). As with their preChristian encounters with nonhuman helpers, Shakers receive the power to heal, fight evil, and predict the future from direct contact with those otherworldly powers (commonly identified as the Holy Spirit) while in a trancelike state. ${ }^{38}$ Songs (monophonic, sung in unison, and unaccompanied, except for the rhythm of handbells) activate "the shake" and, like the power songs received from spirit helpers, have divine origins. As Quinault woman Patricia Sanchez explains, the acquisition of this gift was not easy and required personal sacrifice:

When you join the Shake, you get your gifts, and . . you get a song. It don't come to you all at once, but you get your song. And you're known by that song. That's so and so's song, and that's so and so's song, and you're the only one who knows it for a while. And it don't come to you all at once, but it comes to you piece by piece. You have to pray and give up what you like, you give something up to get a piece of that song. You give something of yourself up to get that song. And your song is your blessing. It's yours. ${ }^{39}$

For Shakers, the songs themselves literally contain God's presence. Songs were used for prayer and worship, to bring the shake to new devotees, to heal, and to console people in mourning. ${ }^{40}$ Just as with preexisting understanding that an individual who received a song from nonhuman sources owned that song, Shakers likewise owned their songs. However, "when a person sings a song for the time at a Shaker service, the rest of the congregation soon learns it and joins in whenever the originator sings it. From that time on, it becomes the recognized property of that individual and is not usually sung unless its 'owner' is

\footnotetext{
${ }^{37}$ James Everett Cunningham and Pamela Amoss, "Song Traditions of the Indian Shaker Church," in Spirit of the First People: Native American Music Traditions of Washington State, ed. Willie Smyth and Esmé Ryan (Seattle: University of Washington Press, 1999), 121.

${ }^{38}$ Amoss, "Indian Shaker Church," 636.

${ }^{39}$ Patricia Sanchez (née Bumgarner), Washington Women's Heritage Project, taped interviews conducted by Winona Weber, 1980-81, University of Washington Library Special Collections accession no. 3416-001, box 9 of Washington Women's Heritage Project, no. T0421f.

${ }^{40}$ Cunningham and Amoss, "Song Traditions," 123-26.
} 
present." ${ }^{\prime 1}$ Over time that song might become public domain and enter into "the treasury of the Shaker song tradition," taught to visitors from elsewhere and carried back to their own congregations. ${ }^{42}$ These apparent parallels between the older spirit powers and Shakerism (such as the reactivation of power through song and performance and the overall "owned" yet shared nature of songs) illustrate the integration, not simply a replacement, of preexisting spiritualities in this new interpretation of Christianity; rather than getting rid of beliefs and symbols, they are indigenized in the Shaker Church. ${ }^{43}$

Externally, Shaker buildings are similar to other Protestant churches or Roman Catholic chapels-generally rectangular wooden buildings with modest steeples. In their interiors, instead of rows of pews, seating is restricted to the outer walls while the floor area (except for a few seats for the sick) is kept open. Men and women sit separately but intermingle in the open space during Shaker work. Services are held on Sundays (either morning or evening) and can be conducted in candle light because of the purifying and healing qualities Shakers attribute to raw flame. The only other item that dominates the interior space is an altar or prayer table covered with a cloth on which a plain cross and the handbells and candles to be used in the service are placed. Shakers have their own prayer tables in their homes for private or small group use. Just before the close of the nineteenth century, church leader Louis Yowaluch (Aiyal), known as "Mud Bay Louis," received a vision of his own that Shakers should wear a special white dress, which later became referred to simply as "the garment"-a white robe with a blue cross on it, to be worn only during Sunday services. Louis reasoned that "in heaven everybody dresses alike, so here on earth on those occasions when Christians are preparing their hearts and minds to enter heaven, they should also clothe themselves in the same way." ${ }^{44}$ While the tradition of special garments has not been carried on by contemporary practitioners, it illustrates the dynamic nature of church practices, and how some have been adopted and then discontinued in the decades since the church's founding. ${ }^{45}$

A Shaker prayer offered in the local Native American language (even

${ }^{41}$ Ibid., 125.

${ }^{42}$ Ibid., 125.

${ }^{43}$ Pamela Amoss, "Symbolic Substitution in the Indian Shaker Church," Ethnohistory 25, no. 3 (Summer 1978): 225-49.

${ }^{44}$ H. G. Barnett, Indian Shakers: A Messianic Cult of the Pacific Northwest (Carbondale: Southern Illinois Press, 1957), 215.

${ }^{45}$ Because of their comparisons between numerous twentieth-century churches, Ruby and Brown's study (John Slocum) is particularly useful at pinpointing other such examples of innovation in practices because of the "gifts" given to individual Shakers. 
if the rest of the service was conducted in English), or sometimes in the Chinook Jargon, opened and closed each Sunday service and was accompanied by the sign of the cross repeated three times-the distinctive Shaker adaptation of the Roman Catholic practice. ${ }^{46}$ Their services make use of other Christian symbols, such as crosses, bells, and candles, during formal Shaker rituals conducted at regular Sabbath services or for funerals, weddings, dedications, and especially "shakes"-where the congregation inducts new members or heals the sick. Indeed, Sunday services contain many elements common to nonnative services, such as the use of prayer, the preaching of sermons, and the singing of hymns. Yet, other elements are distinctive to this indigenous form, notably the practice by which the congregation moves counterclockwise three times around the floor, following the lead of the bells. Next comes an affirmation of fellowship: "beginning with the women, every member of the congregation circles the church in a set pattern touching hands with everyone else." ${ }^{\prime 7}$ If a "shake" is required to heal someone, these last two elements of the service are expanded, with converts or the sick standing or seated in the center of the church, where they are brushed and prayed over through songs, bells, or shaking. Shaking as a symptom of empowerment is a practice that predates the founding of the Indian Shaker Church. Shaking or quivering indicates contact with and activation of power among the Xwélmexw and dxwlešucid (e.g., shamans' hands during curing ceremonies or religious leaders trembling while using power boards or poles). ${ }^{48}$

From the early days of the church, existing kinship networks facilitated the spread of the Shakerism within Coast Salish territories. These social ties that bound communities and families together, despite the reservation system, were the most important mechanism in the early years of the church. Anthropologists Erna Gunther and Pamela Amoss, who have studied Shakerism extensively, both identified two initial phases of church expansion that occurred among Pacific Northwest groups: the first occurred in the early to mid 1880s among Salish groups, and the second in the 1890s, when it moved beyond the Coast Salish

\footnotetext{
46 "During early times, Shakers prayed in several native languages at once, producing sounds that, to white ears, were more cacophonous than choral. Chinook Jargon helped congregations adjust to the problem of linguistic diversity. Eventually, English became the dominant language spoken in services, although the intonations of prayer, with words in crescendos and diminuendos trailing off to a whisper, can be unintelligible to strangers" (Ruby and Brown, John Slocum, 91); see also Amoss, "Indian Shaker Church," 636.

${ }^{47}$ Amoss, "Indian Shaker Church," 638.

${ }^{48}$ Jay Miller, Shamanic Odyssey: The Lushootseed Salish Journey to the Land of the Dead (Menlo Park, CA: Ballena Press, 1988), 17.
} 
world. ${ }^{49}$ Unsettled conditions brought about by the First World War and the Spanish influenza epidemic in the war's wake also prompted a period of church expansion. ${ }^{50}$ Naxaxalhts'i/McHalsie's description of the emergence of a sxwó:yxwey mask around the time of a devastating smallpox epidemic in 1782 throughout S'ólh Téméxw points to the cultural precedence of spiritual innovation coinciding with times of illness, and to the associations of such expressions with healing power. ${ }^{51}$ Whether by new converts to Shakerism carrying what they had learned back to their home communities, or by relatives requesting healing services that when successful contributed to the church's appeal, or simply because of the close social ties that existed between communities in general, the reach of the Indian Shaker Church continued to expand.

Shortly after the first meetings in the early 1880s, "Big John" led a public parade of nascent Shakers through the streets of the state capital, their procession announcing their presence to natives and nonnatives alike. ${ }^{52}$ Met with ridicule and disdain by both groups, John was subse-

\footnotetext{
${ }^{49}$ Shakerism first circulated in the Puget Sound region stretching outward from the southern end of the sound where it had first originated at Mud Bay on Squaxin Island to adjacent areas in Skokomish, Oakville, and Chehalis by 1883 to Jamestown and Port Gamble in the north by 1885 . From Clallam territory in the north end of Puget Sound it crossed the Strait of Juan de Fuca and the international border into British Columbia, carried by aboriginal migrants to Beecher Bay on Vancouver Island. From there it spread to Lekwammen (Songhees) who lived at Esquimalt and Victoria, and later to Saanich and Koksilah through marriage. Visitors to some of these communities likewise converted to the church and its practices, and carried it to their own home communities on the mainland of British Columbia. By the mid-1880s, diffusion seems to have temporarily slowed, only to be revived again in the early 1890s. It next spread along the west coast of Washington, moving through Quileute territory and to the Makah (Nuu-chah-nulth) at the most northerly part of the state at Neah Bay. About the same time, converts carried it to the southeast. In 1890, Cowlitz learned of Shakerism from relatives who carried it to the Yakima. The Yakima Shaker Church thrived, and after 1908 a seventy-nine-acre land grant in the middle of the reservation gave it a security in property and for several decades provided the congregation agricultural income. It was through the Yakima Shakers that Oregon (Siletz, Warm Springs, Klamath) and California (Smith River, Hoopa in the 1920s) Indians came into its fold. The Shaker Church does not seem to have moved much further east. Amoss ("Indian Shaker Church," 634-36) argues that the "eastward movement of Shakerism was slowed by the resistance of entrenched Christian missionaries or local prophet movements" (634), though it did reach Umatilla Reservation near Pendleton, Oregon, in 1906. Information on initial dissemination patterns are discussed in Gunther, "Shaker Religion," 42-48; Barnett, Indian Shakers,45-85; and Kew, "Salish Ceremonies," 24.

${ }^{50}$ Although Gunther ("Shaker Religion," 46) does not discuss it, I cannot help but wonder whether the Spanish influenza that followed in the wake of the Great War may have heightened interest in Shakerism for its healing services.

${ }^{51}$ Naxaxalhts'i/McHalsie, "We Have to Take Care," 112-18; Albert (Sonny) McHalsie, "Sxwó:yxwey Origins and Movements," in Carlson, Stó:lo-Coast Salish Historical Atlas, 1011 .

${ }^{52}$ Edwin Eells Papers, MS 76, box 1, folder 39, "Autobiography of Edwin Eells," ed. by Ida Eells (manuscript) re: Indian Agency and Reservations, Washington State Historical Society Reading Room, Tacoma.
} 
quently arrested for violating the ban on "medicine-men" and dancing and was jailed. ${ }^{53}$ As the church organized itself, it took more direct steps to encourage new members by following conventional missionary techniques that ultimately produced more desirable results. The church licensed its own missionaries, and the activities of some of its early pioneers facilitated the winning over of new converts. Mud Bay Louis Yowaluch (Aiyal) was particularly prominent, second only to Slocum himself, and, according to Gunther, "stands out as an aggressive organizer who was probably responsible for the early spread of the church." ${ }^{\prime 54}$ Another example is Alex Teio, head elder for the church in the 1910s and 1920s. Teio traveled extensively throughout the Pacific Northwest (including British Columbia, Oregon, and Washington) on behalf of the church. Only a fraction of his correspondence has survived, donated by his grandson, Harris Teo (himself a former bishop of the church) to the Washington State Historical Society. What is available of it readily illustrates the wide-ranging nature of Alex Teio's visits..$^{55}$ One of Teio's chief tasks was to assist new churches in setting up their organizational structures, from issuing preacher, elder, and assistant elder licenses to answering requests for bells and candles. He also responded to calls for healing services.

Indeed, successful healing work prompted many Native American communities to embrace Shaker teachings. It appears to have been commonplace for those healed by Shakers to become powerful and convincing advocates for the church and its spread. ${ }^{56}$ Shakers traveled widely for this very purpose. When the church first emerged in the 1880s, Native American communities throughout the Pacific Northwest had been suffering from a series of epidemics; "the Slocums discovered God's power to heal Indians at a time when physical and psychological distress afflicted many people they knew." 57 "One of the reasons why the Indian Shaker church was so successful in this region," explains anthropologist June Collins, "is that it did and still does have treatment of the illness caused in the traditional way," that is, to cure a sickness derived from "supernatural" causes rather than pathogens (although

\footnotetext{
${ }^{53}$ Ruby and Brown, John Slocum, 46.

${ }^{54}$ Gunther, "The Shaker Religion," 43.

${ }^{55}$ Correspondence, 1911, MS 29, box 3, folders 42-53, Indian Shaker Church of Washington Records, Washington State Historical Society Reading Room, Tacoma.

56 "Ties of blood and marriage between communities were the primary links for dissemination of new ideas, but it was the Shakers who traveled to help the sick who made the dramatic appeal to converts" (Amoss, "Indian Shaker Church," 634). This is also a familiar pattern cited in H. G. Barnett, "Adding Converts," in his Indian Shakers, 45-85.

${ }^{57}$ Alexandra Harmon, Indians in the Making: Ethnic Relations and Indian Identities around Puget Sound (Berkeley: University of California Press, 1998), 126-27.
} 
Shakers also seek to "cure" what they regard to be moral sins like alcoholism or drug abuse). ${ }^{58}$ Just as shamans blew or removed foreign objects from patients suffering from spiritual illnesses, church members' shaking, songs, and sometimes rubbing the bodies of the sick person during healing services removed the causes of ill through the intercession of the Holy Spirit.

Another way of disseminating religious identities in the Pacific Northwest was through the multitribal, cross-border points of meeting that occurred as a result of Native American involvement in the wage labor economy. The Shaker Church benefited from these cross-border movements. Old and new religious practices, shamanic and Christian powers were utilized regularly even as natives participated in the wage-labor economy. Missionaries followed their people to the salmon canneries and hop fields to care for the spiritual needs of their flocks while at work. Shakers also ministered to the sick in work camps or on farms when ill health plagued workers. As Raibmon describes, "in the 1890s, the Shaker religion traveled a trajectory remarkably similar to the seasonal economic cycles of Aboriginal people. ${ }^{59}$ Missions and churches saw not only visitors from neighboring reservations but also those who had traveled great distances to find employment or to visit kin. Combined with pantribal "treaty days" or annual congregations of natives to celebrate the Fourth of July or Dominion Day, the exchanges of religious ideas were a part of the socializing. ${ }^{60}$ Throughout, opportunities to shape Christian forms, such as Shakerism, to the needs that best served native peoples abounded.

\section{CRITICS IN THE AUDIENCE: NONNATIVES RESPOND TO THE SHAKERS}

Hitherto, I have described the Xwélmexw and $d x^{w}$ lašucid reception to the Indian Shaker Church. How did nonnative missionaries feel about this vernacular Christianity? In general (and not surprisingly), many missionaries met the emergence of the Shaker Church with hostility. One of the first and most vehement was Myron Eells, the Congregationalist missionary working on the Skokomish Reservation near Mud Bay when and where the movement was born. He arrived in 1874 and immediately he condemned both traditional forms of Native American spiritual expression (which he labeled tamahnous, using the Chinook Jargon) and

${ }^{58}$ Collins, Valley of the Spirits, 205.

${ }^{59}$ Raibmon, Authentic Indians, 111.

${ }^{60}$ Barnett, Indian Shakers, 45; Amoss, "Symbolic Substitution," 236, 243. The Shakers themselves set July 4 as the date of their annual camp meeting, held at the mother church at Mud Bay. 


\section{The Journal of Religion}

the version of Christianity offered by his Roman Catholic rivals. Eells was also especially perturbed by the Shakers when they appeared a decade later. Indeed, at least one historian has wondered whether or not his persecution actually contributed to the development of "a syncretic resolution of competing claims for their spiritual allegiance," that half the reservation seems to have found in the Slocums' new church. ${ }^{61}$

In the summer of 1883 Eells struggled against what he saw as three distinct indigenous movements that threatened his mission. Not only was there what he referred to as the "dark days" of the Slocums' Shakerism, but Eells also railed against the self-styled Roman Catholicism of a native man, Billy Clams, and also against the activities of "Mowitch man," who had been a follower of the Slocums until visions caused him to develop a sect of his own. His account describes the depth of religious excitement that drove Salish peoples away from Eells's church and into the newly formed Shaker Church, and for that reason is worth citing at length:

Affairs went on about the same until August. The report then was that Billy Clams had been to John Slocum's and that they had arranged to have a great time. He came back and an invitation was extended to the whole reservation to go to John Slocum's, where it was said that four women were to be turned into angels; they would receive revelations directly from heaven, and many wonderful things would be done. Two logging-camps out of four were shut down completely for the time and some people went from one other. They were told that they would be lost if they did not go; that the baptism of those whom I had baptized was good for nothing, being done with common water, and that they must go to be baptized again, and that the world was coming to an end in a few days. About thirty-five Indians went from here and many from other places, and there was great excitement. Some Roman Catholic ceremonies were held, something similar to the old black tamahnous ceremonies being added to them. These put the patient into a state somewhat like that of a mesmerism, baptizing it with the name of religion. Visions were abundant; four people, it was said, died and were raised to life again; women, professing to be angels, tried to fly around. People went around brushing and striking others until some were black for a week, the professed intent being to brush off their sins. A shaking took hold of them, on the same principle, I thought, that fifty years ago nervous jerks took hold of some people of the South West at their exciting camp-meetings; and this continued with them afterward until they gained the name of the shaking set. Some acted very much like crazy people, and some indecent things were done. It was reported that they saw myself, Mowitch man, and others in hell; that I was kept on the reservation to get the lands of the Indians away from them, and that I told lies in church. Such reports came to the reservation after a few days that the teacher here, who was in

${ }^{61}$ Harmon, Indians in the Making, 127. 
charge of the reservation, thought that he had better go and see it and perhaps try to stop it. He took two policemen and the interpreter with him and went there. He stayed one night and talked to them so plainly that they returned a day or two afterward; but their nervous excitement was not over. Some of them, as they returned, went to their homes, and a little cooling off, together with the talk of their friends, brought them to their senses; but about half of the number kept on. ${ }^{62}$

Myron Eells assessed Shakerism as a blending of Roman Catholic ceremonies and older spiritual practices. He mentions the "work" of curing sins through the brushing of a person's body and by shaking over and around the patient. Eells's passage also reveals other aspects of Shakerism that provoked the ire of others in the vicinity, for example, their ability to interrupt local economic activities (e.g. logging camps were closed). The reservation's teacher, interpreter, and police intervened to attempt to repress the Shakers. While Eells's memoirs suggest a small victory and a quelling of the original intensity of the faith, this would prove to be only temporary. The Shaker Church soon entered its phase of rapid expansion in the early 1880s and again in the 1890s.

The rumor that Eells had been envisioned in hell echoes what this missionary has written elsewhere-an interpretation of Shakerism as one of the many nativistic movements (such as the Ghost Dance of the Plains Indians) among western Native American peoples in the late nineteenth century that were less accommodating to the colonial newcomers. He and other Americans feared the Shakers as a potentially dangerous barrier to the continued nonnative occupation of Indian lands despite there being no explicit evidence to support such concerns. In 1899, he wrote that the church's leader had promised his followers: "If they would stand by him altogether, he would shake away the Indian court, the judges, the agents, the agency, laws, influences and restrictions; that indeed, he would shake away all the whites in the country and bring back the old days to them all, with freedom, license, and everything that then existed. . . . These facts show that the Shaker religion without the leaven of pure Christianity and all the good there is in it, would not make a safe place for any one." ${ }^{63}$ Shakers defied many of these colonial powers, but they do not seem to have targeted them to disappear. Theirs was a countercolonial performance that contained both ancient and newer spiritual ways, representing at once change and continuity while following the typical path of religious innovation for

\footnotetext{
${ }^{62}$ Myron Eells, Ten Years of Missionary Work among the Indians at Skokomish, Washington Territory, 1874-1884 (Boston: Congregational Sunday-School and Publishing Society, 1886), 172-74.

${ }^{63}$ Myron Eells, "Tacoma on the Skokomish Reservation," The Indian's Friend 21, no. 6 (February 1899): 9 .
} 
Xwélmexw and $d x^{w}$ lašucid. The promise of the church and the power exercised by its members was more transcendental than Eells feared, with their priorities on healing and not harming (something that echoed their original opposition to traditional shamanism).

Early Shaker leaders and practitioners were arrested. Church services were severely restricted, which impeded "the work" and certainly the freedom of religious expression Shakers expected under American law. Ironically many were arrested for practicing traditional shamanism, which at this time they openly condemned ${ }^{64}$ Indian agents prompted reservation police to arrest Shaker ministers, although not all complied. For instance, Edwin Eells (Myron's brother), the agent for Skokomish, discovered that one of his best Indian officers, "Old Sandy," had become a Shaker and resigned his commission rather than carry out Eells's order. ${ }^{65}$ Two Shaker ministers at La Push, Washington, wrote a letter to the church's organizer, Milton Giles, in 1911 asking for clarification as to what protected licensed preachers were allotted under the law. During their church services they were harassed by local authorities: "The police \& judge standing on the door on the Shaker meeting to watch our time \& stop our Shakes meeting 3 hours, so we dont like that. We want to get free $\&$ help who is sick with the power we got from God so we ask you if we will do that all the time or will this license will make us free." ${ }^{66}$

There were some exceptions to missionary denouncement of Shakerism. Sarah Endicott Ober, who worked as a teacher's assistant on the Makah (a Nuu-chah-nulth people) Reservation at Neah Bay on the most northerly tip of the Washington Pacific Coast appears to have been quite sympathetic to Shakerism and viewed it a positive stage in the spiritual development of native peoples (although other Presbyterian missionaries on the same reserve were clearly not happy about the new form of Christianity among them) ${ }^{67}$ Initially sceptical, Ober later

\footnotetext{
${ }^{64}$ See, e.g., Tulalip Court records, June 1, 1902, Erna Gunther Papers, accession no. 6141, box 7, folder 2, University of Washington Library and Special Collections.

${ }^{65}$ For an example of an arrest of a minister for conducting Shaker services by the Indian police and a local judge, see Carl J. Black, letter to Peter Heck, April 13, 1912, Indian Shaker Church of Washington Records, MS 29, box 3, folder 44, Washington State Historical Society Reading Room, Tacoma; for Indian agent Edwin Eells's discussion of his Shaker policeman, Old Sandy, see Edwin Eells Papers, MS 76, box 1, folder 39, "Autobiography of Edwin Eells," ed. by Ida Eells (manuscript) re: Indian Agency and Reservations, Washington State Historical Society Reading Room, Tacoma.

${ }^{66}$ Robert E. Lee, head minister and John Johnson, assistant minister, letter to Milton Giles, March 10, 1911, La Push, WA, Indian Shaker Church of Washington Records, MS 29, box 3, folder 44, Washington State Historical Society Reading Room, Tacoma.

${ }^{67}$ For an example of conflict between Presbyterian missionaries and Shakers at Neah Bay, see Barnett, Indian Shakers, 204-5.
} 
changed her opinion. Her description also speaks to the cross-border dissemination of the church:

I found their lives so Christ-like that I felt the hand of God was in that religion, and that only His power could so change and keep them from sin. So I began to study and investigate, and God has led me very wonderfully among the coast tribes from the northern part of the dreadful west coast of Vancouver Island to the Columbia river. Everywhere I have found the same results; wherever the Shaker religion has penetrated, in regenerated lives, and clean, godly people. I have attended two large Shaker conventions, one on the Straits of San Juan de Fuca, and the other among the Cowhichans on Vancouver Island. At both I saw several hundred of Indians gathered for religious services, and holding their meetings day and night, and truly felt that the Holy Spirit was in their midst. At Jamestown where in former years the Clallams were notorious for their drunkenness and debauchery, I found a village that was now noted for its sobriety and righteous living. It was as delightful to be with men and women who were continually engaged in prayer as it used to be to attend the Northfield Conference. ${ }^{68}$

Ober acknowledged how many of the very objectives of nonnative mission work had been achieved through this Native-led version of Christianity, particularly conducive to temperance and moral living. But as with Eells and other missionaries, she could not accept the source of authority for this new religion. Later in the article, she does voice concerns over Shaker healing practices and the elements she sees as having been retained from preexisting beliefs: "My motive for investigating and studying Shakerism is to endeavour to discover some means whereby it can be purged from what is not of God, and brought into real Christianity." ${ }^{9}$

Despite perhaps his own brother's reservations, Indian agent Edwin Eells likewise softened his original negative assessment of the Indian Shaker Church over time. In his memoirs, he confessed that it had done Salish peoples some good: "It has seemed to me that this religion is a real advance on their old religion even if some things do seem strange or objectionable." ${ }^{70}$ In the early twentieth century, Canadian Methodist missionary C. M. Tate was welcomed to speak at a Shaker gathering, although his journal entries reveal that he viewed the occasion much as Ober did, that is, more as an opportunity for educating Native attendees on what he saw as a truer form of Christianity:

\footnotetext{
${ }^{68}$ Sarah Endicott Ober, "A New Religion among the West Coast Indians," Overland Monthly and Out West Magazine 56, no. 6 (December 1910): 590.

${ }^{69}$ Ibid., 594; emphasis added.

${ }^{70}$ Edwin Eells Papers, MS 76, box 1, folder 39: “Autobiography of Edwin Eells," ed. by Ida Eells (manuscript) re: Indian Agency and Reservations, Washington State Historical Society Reading Room, Tacoma.
} 


\section{The Journal of Religion}

Sun 22 [Oct 1922] Left home between $7 \& 8$ A.M. \& Reached the Shaker camp on the West Saanich Road at 9 A.M. The Shaker service commence at 10 led by an Indian from Yakima, Wash. who asked me to preach. I embraced the opportunity of giving the gospel to a mass of superstitious Indians from all parts of Wash \& the southern tribes of British Columbia. Preached at Esquimalt in the afternoon, and attended service at Jas [James] Bay at night. ${ }^{71}$

Shakers themselves were not confused over the authentic nature of their church, consistently defining it as an indigenous form of Christianity. While there are some nonnative members, the church today remains primarily a Native American institution in both Canada and the United States. In a letter from Yakima minister Enoch Abraham to Chehalis bishop Peter Heck in 1911, Abraham described what he had recently told his Shaker congregation: "how we shakers don't have to wait or look at the Government or white people missionarys [sic] to show us how to carry our religion. I told them that we have to do everything ourselves that the religion needs."72 "Although the symbols of power-candles, bells, churches, cross, and garment-were modeled on Christian prototypes, they were seen by the Indians," observed anthropologist Pamela Amoss, "to have come directly from God, not through the mediation of Christian missionaries and their teachings. The uses the founders made of them mark them as Shaker, not as Roman Catholic or Protestant." ${ }^{\text {"3 }}$ The primacy of oral sources of authority over written ones stemmed naturally from the experience-based nature of this religion. This characteristic harkens back to a much older (although also persistent) preference which, as anthropologist Crisca Bierwert explains, remains a central tenet of spirit dancing or longhouse religion among Xwélmexw:

In Coast Salish longhouse religious discourses, orality prevails. No speeches are written in advance; "speaking from the heart" alone is valued. What is said must be remembered, for it is repeated only in speech, not in print. Actions, less liable to be captured in print, are moved from the heart as well, and remembered. Thus where a follower of another religious tradition might find sacred communication in a written text, longhouse followers must listen for "teachings," stories, images or instructions that are remembered spontaneously. ${ }^{74}$

\footnotetext{
${ }^{71}$ Tate Family Papers, MS-0303, box 3, file 2: diary of Rev. C. M. Tate, 1912-32, British Columbia Archives, Victoria.

${ }^{72}$ E[noch] Abraham, letter to Peter Heck, May 2, 1911, White Swan, WA, in box 3, folder 46, correspondence, 1911, Indian Shaker Church of Washington Records MS 29, Washington State Historical Society, Tacoma.

${ }^{73}$ Amoss, "Resurrection, Healing, and 'the Shake,"” 99.

${ }^{74}$ Crisca Bierwert, Brushed by Cedar, Living by the River: Coast Salish Figures of Power (Tucson: University of Arizona Press, 1999), 112. In contrast to the vitality of orality, texts separate words from context, making them lifeless. Bierwert's work explored a particular period of
} 
Indeed, the discussion over whether or not to use the Bible in Shaker services as recorded in the minutes of the annual convention or elders' meetings in the 1920s-1940s often reiterated this very point about the need to "speak from the heart" on spiritual matters. Attendee Beatrice Black at the 1943 meeting put it this way: "This religion was given to us because we did not know how to read the bible. When I want to hear your bible I go to another church. There was no bible in the church when I first joined. I believe in the bible myself but I go to a place where it is used." ${ }^{\prime 5}$ The acceptance or rejection of the Bible proved to be deeply divisive within the church, perhaps because others, like Black, did not associate the Bible with an indigenous Christianity-highlighting tensions between oral and textual religious influence. For a while the existence of two bishops (one pro-Bible, the other against its use in Shaker services) threatened the very organizational stability of the church, and several congregations broke with the mother church over this issue. ${ }^{76}$

Regardless of the position on the Bible, the format of Shakerism as a special gift from God specifically given to and maintained by native peoples is typical of Shaker historical narratives about the church, such as this one found among the records of the Indian Shaker Church:

About 62 years ago this church was originated near Olympia (Mud Bay) in the state of Washington by some Christian Indians based upon their belief in the death and resurrection of John Slocum, one of the Mud Bay tribe. The Church was based upon the principles of the Christian religion. It was proven in good authority at some time or another that its principles are in accord with the words in the Bible. Its strength among the native people comes from the fact that it is an entirely native Church. It was begun by native men and has been for sixty-two years kept up and maintained, and is now one of the established churches in the state of Washington, Oregon, California $\mathcal{E}$ British Columbia, and is entirely controlled by the Indian people. They are very proud of their Church and are making an earnest effort among themselves to practise the Christian religion after forms established by themselves. It is true that the Shakers are noisey worshippers in the sight of men. They Dance for hours; ringing of hand bells as their music; and uses candle for purity light in their church. They Preach according to Powers they received in their

time (the 1980s) when writing and oral traditions were deemed antithetical and in contradiction with one another in terms of the practice of longhouse dancing.

${ }^{75}$ Minutes of the State Board of Elders meeting for the Shaker Church, held at Port Gamble, Washington, March 20, 1943, 4, Records of the Indian Shaker Church of Washington and the Northwest, 1892-1945, Washington State Library, Olympia, accessed on microfilm A4547, University of Washington Library.

${ }^{76}$ For an explanation of how the church schisms played out, see Barnett, Indian Shakers, 107-40; Ruby and Brown, John Slocum, 173-215; Marilyn Claire Richen ("Legitimacy and the Resolution of Conflict in an Indian Church" [PhD diss., University of Oregon, 1974], 634, 636) argues that the Bible only highlighted existing factionalism within the church. 
meetings. When they are controll by the spirit, they can do many mirackles. Many are healed of Drunkedness, and bad habits. ${ }^{77}$

The exclusivity of the Shaker Church's origins as a gift from God to Native American peoples was well asserted, but this did not necessarily extend to a belief in exclusivity of church membership or having to hold Shaker beliefs above all others. Put another way, as Alexandra (Sasha) Harmon writes, "on an indigenous foundation the Shakers fashioned a new self-concept. . . . They found a basis for asserting and taking pride in their ascribed Indian identity." ${ }^{78}$ But it was not the only spiritual identity. When considering the religious identities of Native peoples, we should be looking for multiple identities that attest to the continuity in rich spiritual life they have had since time immemorial. When evaluating the performative nature of the native-newcomer encounter with respect to religion, Shakerism was one such identity that meshed the two sides on Native American terms or rather, under native direction.

Shakerism may have permitted Native American peoples as individuals to maintain not only a unique native Christian identity (i.e., Shakerism as a syncretic identity, an indigenous form of Christianity) but also simultaneously a religious dualism (embracing Native American spiritualities while also becoming Christian) because it incorporated both old and new beliefs. Conflict between Shakers and Spirit Dancers in some communities has been marked, and the identification of the latter as an "ancient religious custom" threatens to cast Shakerism in opposition to indigenous religion instead of an expression of it. ${ }^{79} \mathrm{How}-$ ever, conflict was not always the typical response between groups. In the 1940s when anthropologist June Collins conducted her fieldwork in northern Puget Sound, she noted a continued belief in spirit powers ( $s \sqrt{ }$ qalálitut or $s \sqrt{ }$ yəw'd) among many Upper Skagit people. Regardless of whether they saw themselves as Roman Catholics or Shakers, most attended the winter dances. She also observed that one group of Shakers "believed that their guardian spirit was transformed into their Shaker spirit or "power." ${ }^{80}$ Another set of members insist that the spirit helpers should be "thrown away," if they cannot be "converted" into a "spirit of God." ${ }^{81}$ Indeed, the multiplicity of religious identification was ap-

\footnotetext{
77 "Indian Shaker Church," unpublished manuscript journal, 30, Records of the Indian Shaker Church of Washington and the Northwest, 1892-1945, Washington State Library, Olympia, accessed on microfilm A4547, University of Washington Library; emphasis added.

${ }_{78}$ Harmon, Indians in the Making, 129-30.

${ }^{79}$ Ruby and Brown, John Slocum, 215.

${ }^{80}$ Collins, Valley of the Spirits, 172.

${ }^{81}$ June M. Collins, "The Indian Shaker Church: A Study of Continuity and Change in Religion," Southwestern Journal of Anthropology 6, no. 4 (1950): 403.
} 
parent in her statement reflecting upon nearly three decades of study among the Upper Skagit people (1942-69): their "religious life showed the greatest strength in continued pre-White beliefs and ceremonies and in the presence of the Indian Shaker church. . . . Music, dance, and mythology, possibly because of their association with the religious life, had strong viability" also. ${ }^{82}$ Some scholars have speculated that the conflict between winter dancing and Shakerism or between shamanism and the Shaker Church has been less in areas in which winter dancing is strong (especially in British Columbia) ${ }^{83}$ Along with the conversion

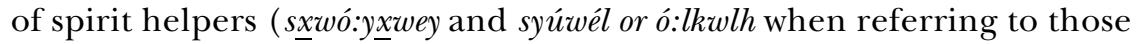
manifest in the winter dance ceremony; $k^{w} a x^{w} a d a d$ ) to the service of God in the "off season," recent attitudes within the church in western Washington and southwestern British Columbia seem to have harmonized the relationship between spirit dancing, shamanism, and Shakers-recognizing all forms and accompanying spiritual identities as paths to betterment for the community as a whole. ${ }^{84}$

THE CRITICS ASSESS THE PERFORMANCE: AN ETHNOHISTORIOGRAPHY OF SHAKERISM

Scholars have long framed the Indian Shaker Church as an institutionalized revitalization movement (also called a prophet movement or messianic cult). Such a movement, according to this conceptual model, revolves around a spiritually empowered individual who attempts to revitalize or recreate a society in crisis through modifying traditional and/or new religious responses. The prophet accomplishes this through contact (frequently after a death) and communication with, and subsequent transformation by, a more-than-human power or being. Receiving a message, the resurrected and returned prophet shares the new belief set and practice with followers. Historically many of these movements entailed nativistic withdrawal from colonial cultures, although not all classified as revitalization movements necessarily rejected Euro-American ways, as was the case with numerous movements that incorporated elements of Christianity.

Drawing on older traditions common to a number of Pacific Coast and Interior Plateau Native American groups, about the end of the world, the resurrection of the dead and the return of mythic time beings, as well as religious innovation (incorporating white or Christian elements in their prophecies), leaders of these movements aimed to

${ }^{82}$ Collins, Valley of the Spirits, 243.

${ }^{83}$ Suttles, "Spirit Dancing," 229.

${ }^{84}$ Amoss, "Indian Shaker Church," 637. 
correct the spiritual imbalance causing crisis and to repair, renew, and revitalize Native societies. Parallels can be drawn between the challenge prophets represented to shamanic power and authority and the reception of Christianity as a new power that both shored up and clashed with traditional forms. Prophets furthered the process of Christianization by spreading knowledge about Christianity and sometimes making use of Christian symbols and practices.

Indeed, revitalization or prophet movements in the historiography, especially those incorporating Christian elements, frequently connected religious encounters between traditional native and Christian cosmologies in general, to the emergence of a phenomenon like the Indian Shaker Church. James Mooney's classic work on the Ghost Dance framed such phenomena within a continuum of spiritual innovation and the universal human desire to revitalize culture and society. Prophet John Slocum and the Indian Shakers were discussed in his The Ghost Dance Religion and Wounded Knee after a lengthy exploration of the Columbia River dreamer prophet Smohalla in the 1870s, which he identified along with the Shakers as the other antecedent to the religious activity on the American Plains in the 1890s. Mooney assessed the significance of the Shakers to be in their ritualistic practices, claiming that a Pauite man named Wovoka, the most famous leader of the 1890 Ghost Dance, acquired "hypnotic secrets" directly from the Shakers. ${ }^{85}$

Leslie Spier's The Prophet Dance of the Northwest and Its Derivative, though an older work caught up in the debate over the precontact or postcontact origins of prophet movements, pays particular attention to the integration of Christian elements into native religions. ${ }^{86}$ In his book Spier identifies the transmission of a religious movement decades before missionaries arrived, including cultural performances with strikingly Christian-like elements (e.g. observance of the sabbath, the sign of the cross) among diverse groups of American Indians throughout the Pacific Northwest, including Salish peoples. Shakerism figures prominently in his study, as it is again deemed a precursor to the Ghost Dancing of the late nineteenth century that was far more reactionary against colonial authorities. Like Mooney, Spier casts native religious movements of the nineteenth century as an essentialist human response to physical and cosmological crises and parallelism in belief and ritual that characterized indigenous North America. In other words, John Slocum emerged with a spiritual solution for his people at a time of severe crises both physical (e.g., disease, appropriation of native lands

\footnotetext{
${ }^{85}$ James Mooney, The Ghost Dance Religion and Wounded Knee, pt. 2, Fourteenth Annual Report of the Bureau of Ethnology (1896; repr., New York: Dover, 1973), 746.

${ }^{86}$ Spier, Prophet Dance of the Northwest, 36-39.
} 
and resources) and cultural (e.g., rise of Christianity through missionization, legal attack on Native American forms of spirituality including dancing and shamanism). Slocum, however, was not necessarily unique-Spier saw him as one among many prophets throughout the century-except in the longevity of the church he spawned.

The prophet movement model is problematic because it casts Native American religious adaptation as reactionary-as a response to colonial pressures. The "born out of crisis" precondition, which in the prophet movement model nearly always was precipitated by Euro-American intrusion, disregards patterns of religious change and innovation that existed before or apart from Euro-American colonialism. This analytical model has proved to be quite enduring. Homer Barnett's classic work on Indian Shakers, written over half a century after Mooney's original investigation, casts the birth of the church within the interpretative framework of a messianic cult, although his consideration of the conditions of Slocum's visions and theological influences on Shakerism thereafter was more sophisticated than earlier scholarly works. For one, his methods were recognizably ethnohistorical, combining five years of fieldwork with archival research. ${ }^{87}$ The church, in his words, "repudiated its heritage [of Native American spiritual practices], refused to accept the status of an affiliate of the established [Christian] religions, developed inspiration and sanction of its own, and evolved a pattern of internal development peculiarly its own." 88 Barnett played up the church's opposition to traditional shamanism within Salish communities. Because this was something that meshed with Barnett's own assessments of shamanism (he called shamans "evil"), throughout the study he gave greater emphasis to Shaker friction with this group-almost as much attention as he gave to exploring tensions Shakers had with other Christian missionaries and organizations. ${ }^{89}$

${ }^{87}$ H. G. Barnett, Indian Shakers: A Messianic Cult of the Pacific Northwest (Carbondale: Southern Illinois University Press, 1957). George Castile ("'Half-Catholic' Movement," 165) has reevaluated Mooney's and Barnett's uncritical use of documentary sources, whereby they failed to analyze Myron Eells's and Wickersham's writings as representing two opposing poles of opinion on the Indian Shaker church.

${ }^{88}$ Barnett, Indian Shakers, 8-9.

${ }^{89}$ While few recent works have adopted the revitalization or prophet movement model, it may yet have application to phenomenon like the Indian Shaker Church. Anthony F. C. Wallace, who originally coined the phrase "revitalization movement" in a 1956 article ("Revitalization Movements: Some Theoretical Considerations for Their Comparative Study," American Anthropologist 58 [1956]: 264-81) and further developed it as a theoretical framework in his classic biography of Handsome Lake (Death and Rebirth of the Seneca [New York: Vintage Books, 1969]) notes that, while the expression itself has been genericized, it has come to be "applied in contexts far removed from situations mentioned as illustrations in the original article" (foreword to Reassessing Revitalization Movements: Perspectives from North America and the Pacific Islands, ed. Michael Harkin [Lincoln and London: University of Nebraska Press, 2004], 
Marian W. Smith's review of Barnett's book in 1959 introduces another comparative framework for understanding Indian Shakers. She calls it a "vitalistic movement," which she defines as "any conscious, organized attempt on the part of a society's members to incorporate in its culture selected aspects of another culture in contact with it." ${ }^{90}$ Later scholars working on the subject continued to reverse the Eurocentric conceptual framework that defined Shakerism as a response to newcomer pressures and opened their analysis of it along Smith's view of syncretism. Scholars began to locate Indian Shakerism within its Coast Salish historical context. Their emphasis on cultural continuity follows, albeit less stringently, frameworks laid out by that anthropological generation weaned on structuralism/structural-functionalism-when anthropology favored explanatory over interpretative constructs of human behavior, whereby finding overarching patterns and determining principles that were used to explain any given culture or society. Wayne Suttles's research on the prophet dance among the Coast Salish revisited some of Spier's prophet dance material and how in the 1830s it arrived in northern Washington and southern British Columbia from the Interior Plateau. ${ }^{91}$ Suttles concludes that the movement-characterized by a marriage dance, the worship of a deity identified as the Chief Above or Most High Respected Leader (Chichelh Siyá:m), and prophecy regarding the arrival of whites-paved the way for later interest in Christianity. ${ }^{92}$ However, Suttles clearly downplayed the reactionary character of the Indian Shaker Church. Indeed, studying Coast Salish cultural expressions in the twentieth century, he identified the Shaker Church as a key cultural institution responsible for the maintenance and expression of Coast Salish identity ${ }^{93}$ In 1987, Suttles argues it remained one of the three systems of intergroup relations that kept Coast Salish culture vibrant (the other two being winter dancing and summer canoe racing). ${ }^{94}$

The Shaker Church, then, provides an organizational link between

\footnotetext{
vii). One direct result has been scholarly use of the revitalization movement model beyond subject matter in which the colonized reacted to pressures of the colonizers through reformation, reinvention, and withdrawal, as essay collections such as Reassessing Revitalization Movements aptly demonstrate. Wallace himself notes that the model is most "congenial to a postmodern scholarly environment, invoking hegemonic Power and the oppressed Other," and "it would seem to be ever more relevant as the tide of globalization washes over the world, producing neo-colonial situations in which "emergent nativisms' . . . flourish in revitalistic response" (ix).

${ }^{90}$ Marian W. Smith, "Toward a Classification of Cult Movements," Man 59 (January 1959): 122.

${ }^{91}$ Wayne Suttles, "The Plateau Prophet Dance among the Coast Salish," in Suttles, Coast Salish Essays, 152-98.

${ }^{92}$ Ibid., 157.

${ }^{93}$ Suttles, "Spirit Dancing," 229.

${ }^{94}$ Ibid.
} 
and among Coast Salish groups and their neighbors, giving them opportunities to assert their indigenous identities and to establish and maintain social status. It followed age-old practices in religious innovation among Northwest Coast peoples. Religious innovation is not always best described by revitalization or prophet movement models so prominent in the historiography, quite simply because post-contact-era religious transformations could and often did occur without interacting with or appropriating elements of Christianity. ${ }^{95}$ Furthermore, beyond this tradition of relious innovation, long-existing social practices may have influenced other elements of the church. Anthropologist Erna Gunther attributed the uniformity and continuity in the rituals of the Shaker church to frequent intergroup contacts-hence the process was circular. "In Washington," she writes describing mid-twentieth-century arrangements, "the old pattern of tribal and village exogamy has continued, and the visiting of relatives has been facilitated by modern transportation. There is rarely a large Shaker gathering where there are not representatives from many tribes and reservations. Whatever is done in ritual, therefore, has wide distribution. ${ }^{96}$ Amoss maintains that the Shakers continue to be respected within their communities for their generosity, sobriety, and power to heal. The church's history stands out as unique: "It was the first fully Indian institution to achieve legal respectability in the eyes of the dominant society at a time when other forms of Indian spiritual expression were actively suppressed"; and "Shakerism affirmed the principle of Indians working together to help each other against the spectres of illness and sin. ${ }^{97}$ In narratives about Shakerism and in terms of religious rituals and functions, Amoss demonstrates how the Indian Shaker Church was successful in the southern

\footnotetext{
${ }^{95}$ One good example of non-Christian religious innovations in the postcontact era is the appearance of new or previously unencountered spirit powers, such as the emergence and spread of sxwó:yxwey masks. Naxaxalhts'i/McHalsie ("We Have to Take Care," 112-18; Mc-

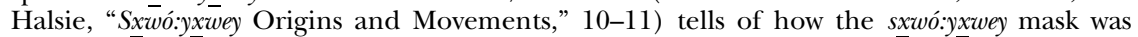
received at the time of the smallpox epidemic in the late eighteenth century, copied, and passed along downriver from one community through the next each time a child in one of the families with hereditary rights to the mask married. Bierwert (Brushed by Cedar, 184, 18790) explains further how this particular sxwó:yxwey is a privilege of certain Salish families in the Halq'emélyem language region but ñot the Lushootseed speaking areas. And yet, she found that it "was more and more called upon to mark important life events, distinguishing not only those families who held the privilege of dancing the sxwayxwey mask but also those families who 'hired' the mask to be danced at weddings, memorials, and so on" (184). She goes on to document the controversy precipitated by the introduction of a new sxwó:yxwey mask in one family which was to be worn by women instead of men, as was the documented convention. Thus religious innovations continue to be both traditionally problematic while also being traditionally dynamic, much as was the case of the Indian Shaker Church in the nineteenth century.

${ }^{96}$ Gunther, "Shaker Religion," 57.

${ }^{97}$ Amoss, "Indian Shaker Church," 639.
} 
and central Coast Salish region because of the kind of symbolic system it developed. ${ }^{98}$ Adopting Christian symbols to replace Native American ones deemed losing power or powerless, the church essentially preserved Native American ideas about spirituality. "It is one of two alternatives," the other one being winter dancing, concludes Amoss, "which affirm the positive value of being Indian." 99 Hence, the symbolic performance that occurs with the practice of religion, functions as an important expression of identity, and once again Native American identification also envelops a Christian identity.

Shakerism historically moved beyond the Coast Salish world, but my argument of countercolonial performance still applies, complementing recent scholarship that likewise rejects dichotomies like native versus Christian or change versus continuity, or models like revitalization movements that cast the Shakers as solely reactionary. For instance, Thomas Buckley analyzed Shakerism in Northwest California as a religious expression that mediated tensions between Christian and traditional ways. He saw the church as one component in a dialogue about Native American identity, especially when placed within the context of a recent (post-1960s) reemergence of Native ceremonialism: "innovations like the Shaker church have indeed been continuations of Native traditions and that-perhaps more difficult to see-reemergent traditions are themselves continuations or evolutions of modern innovation like the Indian Shaker Church." ${ }^{100}$ Buckley pointed to the degree to which dissention and controversy within Californian Shakerism have always been about "Indian identity" — ranging from debates over the Bible versus "the Shake" as the source of religious authority and power to how some religious traditionalists viewed the Shaker Church as the foreign and nonnative side (because they considered it a "pan-Indian" and Christian movement) challenging local and indigenous religious forms (i.e., the "Indian ways" of the Tolowa, Yorok, or Hupa). ${ }^{101}$ Buckley writes, "While converted elders quietly defended the Church as a "continuation' of traditional ways, they seemed, to some, to be deluding themselves in a struggle to maintain their Indian identities while becoming pseudo-Christians. But even outsiders do well to listen closely to what the elders say and to think on it, as local people well know." ${ }^{102}$ As Susan

\footnotetext{
${ }^{98}$ Pamela Amoss, "Symbolic Substitution," 225-49, "Resurrection, Healing, and 'the Shake," 87-109.

${ }^{99}$ Amoss, "Symbolic Substitution," 227.

${ }^{100}$ Thomas Buckley, "The Shaker Church and the Indian Way in Native Northwestern California," in Native American Spirituality: A Critical Reader, ed. Lee Irwin (Lincoln and London: University of Nebraska Press, 2000), 256-57.

${ }^{101}$ Ibid., 262.

${ }^{102}$ Ibid., 256.
} 
Patterson, another scholar of Northwest Californian Shakerism argues, the church is a "curator" for regional cultural traditions and the key to maintaining distinct cultural and spiritual indigenous identities. ${ }^{103}$

Except for filtered information supplied by anthropological informants, insider perspectives in the scholarly literature or the primary textual record on the church for that matter are limited. The authors of the most recent monograph exclusively on Indian Shakerism (written at the request of the Shakers themselves), Robert Ruby and John Brown recount the history of the church on relatively sympathetic terms, drawing heavily on church archives unavailable to earlier scholars and on oral interviews with church members. ${ }^{104}$ Scholarly in approach (although more narrative than analytical overall), this sympathetic and detailed work attempts to incorporate personal perspectives and experiences. While it celebrates the longevity of Shakerism, it focuses heavily on divisions and church schisms. The authors end the book with statements about contemporary threats the Indian Shaker Church faces, particularly how it continues to lose members to religious alternatives (neoshamanism, Smokehouse religion, nonnative Christian churches, especially Pentecostalism). Wade Le Roy, a Shaker informant who had been a secretaryorganizer for the White Swan church, identified education as the reason behind the decline in numbers of Shakers: "Education, he said, had negated and threatened the revelatory aspects of Shakerism, citing the Biblical passage, 'The letter killeth,' to prove his point."105

Hence, again one returns to a key tension within the church: oral and textual authority and the value of "speaking from the heart." More community-level and tribal histories of Shakerism are needed in order to better understand how this played out in the Shaker community and to understand local variations of the church. ${ }^{106}$ Moreover, the oral record is likely the greatest source of information about what Shakerism means in terms of a Native Christian identity and of what I have referred to in this essay as the "countercolonial cultural performance." Regional insights too may help to get a better sense of the "lived" impact of the church, and such perspectives will undoubtedly draw heavily upon Shakers' voices. For example, there are about half a dozen narratives re-

\footnotetext{
${ }^{103}$ Susan Pamela Patterson, "Movers and Shakers: Spirit and Power in Native Northwestern California" (PhD diss., Brown University, 2002).

${ }^{104}$ Ruby and Brown, John Slocum, xix-xx.

${ }^{105}$ Ibid., 232.

${ }^{106}$ Paul Lehnhoff ("Indian Shaker Religion," American Indian Quarterly 6, nos. $3 / 4$ [AutumnWinter 1982]: 288) observed in his analysis of scholarly writings about the Shaker Church that the diversity in forms of Shakerism resulting from the diversity of the native peoples who embraced it, the value and religious sanction given to individualism within the church itself, and the flexibility of religious interpretations all explain the dynamic quality of its history.
} 
corded by Native American women as part of the Washington Women's Heritage Project that speak directly about the Indian Shaker Church in that state. ${ }^{107}$ Their stories are unequivocally imbedded within family and kinship connections. Indeed, they all placed their discussions of Shakerism among the rhythms of daily family life. All of the narratives discussed the decline of spiritual powers (both shamanic and Shaker) among native peoples in the Pacific Northwest in the twentieth century. "There's no power left anymore in there in the Shake we have today," laments Quinault woman Myrtle Landry after reflecting upon the vitality of the Shakers of her youth, particularly her own grandparents, in the early twentieth century. ${ }^{108}$ Yet, paradoxically, Landry's and the other women's narratives confirm the endurance and persistence of empowered native individuals who wield their gifts for good or harm (some of the topics covered are the gift of second sight, showdown with shamans, the healing powers of Shakers of both physical and spiritual sicknesses). In fact, that the Indian Shaker Church still exists is a testament to the continuity of the ability to access spiritual power through performance and ritual among Coast Salish/Puget Salish peoples.

\section{ENCORE PERFORMANCE: GATHERING IN THE SPIRITUAL BORDERLANDS}

Contrary to scholarly analysis favoring "revitalization" or "vitalization" movements, Shakers do not appear to view themselves as the inheritors of a Christianized prophet movement, one of many such spawned from the decades of turmoil, death, and dispossession that characterized the close of the nineteenth century. Rather, this gift of a Native version of Christianity was deemed unique. Nor was it at odds with the old ways despite the church's original opposition to traditional religious practitioners. For some native groups (e.g., the Tolowa of California), "traditionalists" founded the church. "Aboriginal ideas about health and spiritual medicine were 'proven' in their personal experiences as Shaker healing workers." 109

Though relatively small in number both historically and today, the

${ }^{107}$ Katherine Berkeley (née Sheldon), Ella Frank (née Johns), Myrtle Landry (née Charley), Doris Miller (née Adams), Mildred R. Pickett (née McCrory), Patricia Sanchez (née Bumgarner), Washington Women's Heritage Project, taped interviews conducted by Winona Weber, 1980-81, University of Washington Library Special Collections accession no. 3416-001, box 9 of Washington Women's Heritage Project, no. T0421f.

${ }^{108}$ Myrtle Landry (née Charley), Washington Women's Heritage Project, taped interviews conducted by Winona Weber, 1980-81, University of Washington Library Special Collections accession no. 3416-001, box 9 of Washington Women's Heritage Project, no. T0421f.

${ }^{109}$ Al Logan Slagle, "Tolowa Indian Shakers and the Role of Prophecy at Smith River, California," American Indian Quarterly 9, no. 3 (Summer 1985): 358. 
Shakers nonetheless exert significant influence. ${ }^{110}$ My research shows that the mechanisms of spreading spiritual forms can reveal much about how Christianity in general had been incorporated into native religions. Native peoples never accepted Christianity as a comprehensive package; rather, it was incorporated selectively into, and even altered, preexisting spiritual practices. Moreover, the creation and dissemination of new identities among American Indians in the Canadian-American Pacific Northwest, be they religious ones or otherwise, were never linear processes. Nor was the acquisition of new identities necessarily the replacement of older ones. Indeed, the constancy of change in the history of the Coast Salish and Puget Salish peoples has been noted by other writers. It could be cause for anxiety, but it had been a reality of life for these people for millennia. ${ }^{111}$

Borrowing from outsiders and adopting practices and ceremonial forms from other cultures has long been a characteristic of Salish cultural innovation. As this essay has shown, religious traditions proved to be no different, even when it meant incorporating ideas from the colonizers themselves. There was no single adaptation or response to colonialism. This can be quite simply exemplified by the person of Eugene Harry, with whom I began this discussion. The man portrayed in the documentary O'Siem is not simply an Indian Shaker, although his identity as such was certainly highlighted throughout the film. Harry is a competitive canoe paddler, a longhouse dancer, a traditional spokesperson, a husband and father-a modern Indian, in other words. Accordingly, when discussing whole communities and groups of Coast Salish and Puget Salish peoples, such as the Xwélmexw and $d x^{i w} l$ šucid, there was no single religious identity that helped them survive in the colonial world. Just as Thomas Buckley has posited, perhaps then the Indian Shaker Church can be effectively interpreted as the discourse by which both "Indianness" and "Christianness" can be declared. Comparatively across borders, Shakerism asserts a "traditional" Indian identity within a Christian context, and a Christian identity within the "tra-

\footnotetext{
${ }^{110}$ In the 1970 s there were fewer than a thousand Shakers in the Pacific Northwest, and contemporary sources estimate membership numbers to be even smaller today. See Richen, "Legitimacy and Resolution," 13; Cunningham and Amoss, "Song Traditions," 121. However, these numbers may be deceiving. Estimations of membership may only refer to active or core church goers and not to those who otherwise associate with Shakerism through relations, as former patients, or as only occasional participants in services.

${ }^{111}$ In Lushootseed, "the word dookw, 'to change' or 'to transform,' is the root for a host of concepts including worry, dissatisfaction, anger, infirmity, and ferocity. At the same time it also the root of the words for 'yesterday' and 'tomorrow'-an indication that change was a constant in indigenous life before the arrival of Europeans and that the "people without history' were a people with a past" (Coll Thrush, Native Seattle: Histories for the Crossing-Over Place [Seattle: University of Washington Press, 2007], 25).
} 
The Journal of Religion

ditional" Indian culture (or "traditional" in a neo-traditional one). In other words, understanding the Indian Shaker Church as a process of identification illuminates the native-newcomer encounter as a culturally mediated performance. 